\title{
ANALISIS PERLAKUAN AKUNTANSI TERHADAP RESTRUKTURISASI KREDIT BERMASALAH PADA PT. BANK RAKYAT INDONESIA (PERSERO) TBK CABANG MANADO
}

\author{
Waworuntu Gicella Brigita ${ }^{1}$, Ventje Ilat ${ }^{2}$, Sintje Rondonuwu ${ }^{3}$ \\ ${ }^{1,2,3}$ Fakultas Ekonomi dan Bisnis. Jurusan Akuntansi. Universitas Sam Ratulangi, Jl. Kampus Bahu, Manado, \\ 95115, Indonesia \\ E-mail : gicellaw24@gmail.com
}

\begin{abstract}
Many creditors have difficulty in returning the bank. Therefore, it is necessary to restructure non-performing loans to minimize outstanding loans. Credit restructuring is an effort used by banks in credit business activities to enable the debtor to fulfill its obligations. Similarly, the Commercial Bank in North Sulawesi, namely PT. Bank Rakyat Indonesia (Persero) Tbk branch Manado which is one of the main activities to provide credit to customers. The largest revenue in PT. Bank Rakyat Indonesia (Persero) Tbk branch Manado comes from loan interest to debtor. From the results of the study, there are still arrears that have congestion. However, PT. Bank Rakyat Indonesia (Persero) Tbk branch Manado has been conducting a restructuring of non-performing loans. This study was conducted with the aim to know and analyze the accounting treatment that is, recognition, measurement, and disclosure to the restructuring of problem loans at PT. Bank Rakyat Indonesia (Persero) Tbk branch Manado. The using methods of the observation is qualitative analysis methods. The results showed that PT. Bank Rakyat Indonesia (Persero) Tbk branch Manado has implemented the appropriate restructuring procedures in accordance with the applicable regulations.
\end{abstract}

\section{Keywords: Restructuring, problem loans}

\section{PENDAHULUAN}

Indonesia adalah salah satu negara berkembang yang perkembangan ekonominya meningkat pesat. Peningkatan ekonomi yang pesat ini diikuti dengan banyaknya peningkatan kebutuhan masyarakat di Indonesia. Di saat kebutuhan meningkat inilah bank-bank memberikan layanan dengan banyak fasilitas, seperti menerima simpanan, menerima pembayaran setoran listrik, air, telepon, pulsa, pajak, uang kuliah, dan pembayaran lainnya termasuk pemberian kredit (Govanda, 2015). Menurut Ivana (2012), bank dalam menjalankan kegiatan usahanya di bidang penyaluran kredit, dihadapkan pada permasalahan risiko yaitu risiko pengembalian kredit sehubungan dengan adanya jangka waktu antara pencairan kredit dengan pembayaran kembali. Ini berarti bahwa semakin panjang waktu kredit semakin tinggi pula risiko kredit tersebut.

Menurut Ermawati (2013), resiko kredit macet dan terganggunya likuiditas dapat mengganggu pelaksanaan operasional bank sehari-hari. Resiko ini dapat diperkirakan dengan menggunakan suatu proses yang disebut dengan analisis kredit. Analisis dilakukan perbankan untuk mengetahui dan menentukan apakah seseorang itu layak atau tidak untuk memperoleh kredit. Bank rakyat Indonesia (BRI) adalah salah satu bank milik pemerintah yang terbesar di Indonesia. Kredibilitas dalam manajemen operasionalnya sudah tidak diragukan lagi. Bank ini menerapkan prinsip mengenal nasabah sebagai bentuk upaya melaksanakan prinsip kehati-hatian. Bank Rakyat Indonesia (Persero) Tbk cabang Manado. Sama halnya dengan bank umum yang lain, PT. Bank Rakyat Indonesia (Persero) Tbk cabang Manado memiliki 
tujuan utama yaitu menghimpun dan menyalurkan dana dari dan kepada nasabah. Dalam melakukan kegiatan operasional tersebut, ternyata Bank BRI memiliki permasalahan berkenan dengan pengelolaan kredit bermasalah.

Permasalahan non performing loan (NPL) pun tidak lepas dari aktifitas operasional PT. Bank Rakyat Indonesia (Persero) Tbk cabang Manado. Pada tahun 2017 besarnya jumlah kredit yang diberikan oleh PT. Bank Rakyat Indonesia (Persero) Tbk cabang Manado, kepada nasabah sebesar Rp. 1.125.000.000.000,- pada bulan September 2017. Jumlah kredit tersebut mengalami kenaikan sejak bulan Maret 2017 sebesar Rp. 825.700.000.000,-. Dari besarnya jumlah kredit yang diberikan tersebut, PT. Bank Rakyat Indonesia (Persero) Tbk cabang Manado membebankan Kerugian Penurunan Nilai Aset Keuangan (KPNAK) atas kredit yang diberikan sebesar Rp. 28.125.000.000,-. Sementara itu pada bulan September 2017 hanya berjumlah Rp. 10.734.100.000,- pada bulan Maret 2017. Kenaikan jumlah kredit yang diberikan sangat berpengaruh terhadap jumlah beban kerugian penurunan nilai asset keuangan. Hal tersebut karena kenaikan jumlah kredit yang diberikan, jumlah beban KPNAK mempengaruhi laba sebesar 1,3\% sampai 2,5\% (perhitungan di luar beban bunga).

Restrukturisasi kredit merupakan suatu terminologi keuangan yang banyak yang digunakan dalam bidang perbankan khususnya di PT. Bank Rakyat Indonesia (Persero) Tbk cabang Manado untuk menyelamatkan kredit bermasalah. Restrukturisasi adalah program bank sebagai suatu usaha perbaikan yang dilakukan dalam kegiatan pengkreditan terhadap debitur yang mengalami kesulitan untuk memenuhi kewajibannya. Melihat fenomena tersebut, penulis tertarik melakukan penelitian pada PT. Bank Rakyat Indonesia (Persero) Tbk cabang Manado untuk menganalisis kesesuaian perlakuan akuntansi yaitu, pengakuan, pengukuran, dan pengungkapan. Dan juga menganalisisi kesesuaian restrukturisasi kredit bermasalah apakah telah sesuai dengan aturan Peraturan Bank Indonesia (PBI), Pernyataan Standar Akuntansi Keuangan (PSAK), dan Pedoman Akuntansi Perbankan Indonesia (PAPI) tahun 2011, tentang retrukturisasi kredit bermasalah.

\section{TINJAUAN PUSTAKA}

\subsection{Konsep Akuntansi}

Menurut Warren, et al (2014:3), akuntansi diartikan sebagai sistem informasi yang menyediakan laporan untuk para pemangku kepentingan mengenai aktifitas ekonomi dan kondisi perusahaan. Akuntansi sering disebut bahasa bisnis (the language of business).Mungkin bahasa yang paling tepat adalah bahasa dari seluk-beluk keuangan (financial). Accounting Princple Board (APB) statement mendefinisikan akuntansi sebagai suatu kegiatan jasa.

\subsubsection{Pengertian Perlakuan Akuntansi}

Setelah dibahas definisi mengenai akuntansi, sekarang akan dibahas mengenai perlakuan akuntansi. Kieso dan Weygandt (1995:92), menyatakan bahwa "Perlakuan akuntansi adalah aturan-aturan atau langkah-langkah yang dilakukan dalam proses akuntansi yang meliputi pengakuan, pencatatan dan penyajian informasi keuangan dalam laporan keuangan perusahaan". Harnanto (2009), mendefinisikan perlakuan akuntansi adalah "Suatu disiplin analisa yang mencakup kegiatan mengidentifikasi berbagai transaksi atau peristiwa yang merupakan kegiatan pencatatan sehingga infomasi yang relevan dan mempunyai hubungan antara yang satu dan yang lainnya yang mampu memberikan gambaran secara layak tentang keadaan keuangan dan hasil usaha perusahaan akan digabungkan dan disajikan dalam bentuk laporan keuangan".

\subsubsection{Pemakai Informasi Akuntansi}

Dalam Hery (2013:6), mengelompokkan para pengguna informasi akuntansi ke dalam dua kategori, yaitu pemakai internal (internal users) dan pemakai eksternal (external users).

\subsubsection{Profesi Akuntansi}


Secara garis besar, akuntan dapat digolongkan menjadi: (1) akuntan publik (public accountants), (2) akuntan manajemen (management accountats), (3) akuntan pemerintah (government accountants) dan (4) akuntan pendidik.

\subsection{Akntansi Perbankan}

Dalam Ismail (2012:14), akuntansi bank merupakan seni pencatatan, penggolongan, pengikhtisaran atas seluruh transaksi yang terjadi di dalam bank. Transaksi-transaksi lain yang dicatat oleh bank meliputi transaksi keuangan maupun transaksi lain yang akan mengakibatkan adanya peristiwa keuangan yang akan terjadi di masa yang akan datang.

\subsection{Peranan OJK (Otoritas Jasa Keuangan)}

Peran OJK dalam Bisnis Bank tidak kalah penting dengan peranan Bank Indonesia. Otoritas Jasa Keungan mempunyai peranan penting dalam kegiatan di sektor jasa keuangan. OJK melakukan pengawasan secara independen dan akuntabel. Peranan OJK dalam pengawasan dan pengaturan bisnis bank sangat luas karena mencakup pengaturan dan pengawasan secara microprudential.

\subsection{Kredit}

\subsubsection{Pengertian Kredit}

Dalam Jayanti (2012), kredit mengandung pengertian adanya suatu perkataan dari seseorang atau badan yang diberikan kepada seseorang atau badan lainnya yaitu bahwa yang bersangkutan pada masa yang akan datang akan memenuhi segala sesuatu kewajiban yang telah diperjanjikan terlebih dahulu.

\subsection{Akuntansi Kredit}

Ismail (2012:198), menjelaskan bahwa kredit dicatat dalam neraca pada saat pencairan kredit sebesar jumlah uang yang dikeluarkan oleh bank kepada nasabah. Pada saat bank memberikan persetujuan kredit dan mengirimkan surat persetujuan kredit kepada calon debitur, maka jumlah plafon kredit yang telah disetujui ini dicatat dalam rekening administratif atau pada kewajiban komitmen "fasilitas kredit kepada nasabah yang belum digunakan."

\subsubsection{Akuntansi Restrukturisasi Kredit}

Kredit yang diberikan oleh bank memiliki tujuan agar uang yang disalurkan dalam bentuk kredit kepada debitur dapat dikembalikan sesuai jangka waktu yang telah diperjanjikan. Namun dalam kenyataanya, dari seluruh kredit yang diberikan masih terdapat kredit yang bermasalah. Dalam hal terdapat kredit yang bermasalah maka, bank berupaya untuk menyelesaikannya.

\subsubsection{Peraturan Bank Indonesia tentang Restrukturisasi Kredit}

Pasal 54 paragraf 54 tentang Perlakuan Akuntansi Restrukturisasi Kredit berbunyi Bank wajib menerapkan perlakuan akuntansi restrukturisasi kredit sesuai dengan standar akuntansi keuangan yang berlaku. Perlakuan akuntansi untuk restrukturisasi kredit antara lain diterapkan untuk hal-hal berikut.

a. Pengakuan kerugian yang timbul; dan

b. Pengakuan pendapatan bunga dan penerimaan lain.

\subsubsection{PSAK No. 55 (revisi 2011) Instrumen Keuangan: Pengakuan dan Pengukuran}

Pernyataan Standar Akuntansi Keuangan (PSAK) 55 telah diterbitkan Ikatan Akuntansi Indonesia (IAI mengenai instrument keuangan yaitu pengakuan dan pengukuran. Revisi PSAK 55 adalah hasil dari mengadopsi seluruh ketentuan dalam IAS 39 Financial Instumens: Recognition and Measurement. PSAK 55 ini diharapkan dapat terciptanya proses harmonisasi penyusunan dan analisis laporan keuangan. Entitas mengakui aset keuangan atau kewajiban keuangan pada neraca jika dan hanya jika, entitas tersebut menjadi salah satu pihak dalam ketentuan pada kotrak instrument tersebut berkaitan dengan pembelian aset keuangan yang lazim (regular) (Ikatan Akuntan Indonesia 2012:55 Poin 16). 


\subsubsection{PSAK No. 60 (revisi 2011) Instrumen Keuangan: Pengungkapan}

Tujuan PSAK Nomor 60 adalah mensyaratkan entitas untuk menyediakan pengungkapan dalam laporan keuangan yang memungkinkan para pengguna untuk mengevaluasi:

1. Signifikan instrumen keuangan terhadap posisi dan kinerja keuangan entitas; dan

2. Sifat dan cakupan resiko yang timbul dari instrumen keuangan yang mana entitas terekspos selama periode dan pada akhir periode pelaporan, dan bagaimana entitas mengelola resiko tersebut (PSAK 60 : paragraf 01).

\subsection{Penelitian Terdahulu}

1. Penelitian yang dilakukan Ngadirin Setiawan (2013) dengan judul Perlakuan Akuntansi Kredit Bermasalah Setelah PSAK No.31 Efektif Dicabut Pada PT.Bank Tabungan Negara. Hasil penelitian menunjukkan setelah efektif dicabutnya PSAK No. 31 pada 1 Januari 2010 tentang Akuntansi Perbankan maka dalam perlakuan akuntansi instrumen keuangan aset, ekuitas, dan liabilitas pada PT. BTN (Persero) Tbk. menggunakan PSAK No. 50 (revisi 2010), PSAK No. 55 (revisi 2011) dan PSAK No. 60 (revisi 2010).

2. Penelitian yang dilakukan Jirry Mayfella Govanda (2015) dengan judul Analisis Perlakuan Akuntansi Kredit Bermasalah (Nonperfoeming Loan) Sebelum dan Sesudah PSAK No.31 Efektif Dicabut. Hasil penelitian menunjukkan setelah efektif dicabutnya PSAK Nomor 31 pada 1 Januari 2010 tentang Akuntansi Perbankan maka dalam perlakuan akuntansi instrumen keuangan aset, ekuitas, dan liabilitas pada PT Bank Internasional Indonesia Tbk. menggunakan PSAK Nomor 50 (revisi 2010), PSAK Nomor 55 (revisi 2011) dan PSAK Nomor 60 (revisi 2011).

\section{METODE PENELITIAN}

\subsection{Jenis Penelitian}

Jenis penelitian dalam tulisan ini yaitu jenis penelitan berdasarkan tingkat ekplanasi, deskriptif.

\subsection{Tempat dan Waktu Penelitian}

Objek penelitian pada PT. Bank Rakyat Indonesia (Persero) cabang Manado, yang bertempat diJalan Sarapung No. 4-6, Wenang Utara, Kota Manado, Sulawesi Uatara.Waktu penelitian dimulai pada bulan Februari.

\subsection{Prosedur Penelitian}

Prosedur penelitian adalah sebagai berikut.

1. Persiapan

Pada tahap ini dilakukan identifikasi masalah terhadap objek yang akan diteliti.

2. Observasi

Setelah melakukan persiapan, selanjutnya akan dilakukan penelitian dengan cara turun langsung ke lapangan untuk mengamati kejadian kejadian dan fakta-fakta mengenai objek yang akan diteliti, selain itu akan meminta data dari pengelola objek untuk dianalisa dan diolah kembali menjadi sebuah tulisan penelitian.

3. Wawancara

Pada tahap ini akan dilakukan proses wawancara dengan karyawan, pada PT. Bank Rakyat Indonesia (Persero) Tbk cabang Manado untuk meminta informasi-informasi penting mengenai objek penelitian.

\subsection{Metode Pengumpulan Data}

\subsubsection{Jenis Data}

Dalam melaksanakan analisis dan pembahasan terhadap masalah dalam penelitian ini, peneliti menggunakan data kualitatif dan kuantitatif. 


\subsubsection{Sumber Data}

Sumber data yang digunakan dalam penelitian ini adalah data primer dan sekunder. Data primer yang digunakan dalam penelitian ini yaitu hasil wawancara mengenai hal-hal yang bersangkutan dengan penelitian ini, sedangkan data sekunder yang digunakan yaitu berupa buku-buku, artikel dan data-data umum dan laporan keuangan instansi PT. Bank Rakyat Indonesia (Persero) Tbk cabang Manado.

\subsubsection{Teknik Pengumpulan Data}

Teknik pengumpulan data dalam penelitian ini yaitu sebagai berikut.

1. Wawancara, yaitu teknik pengumpulan data yang dilakukan dan diperoleh dengan mengadakan tannya jawab sambil tatap muka antara pewawancara dengan karyawan, divisi kredit bisnis, divisi kredit consumer, divisi akuntansi dan laporan keuangan dan divisi corporate secretary pada PT. Bank Rakyat Indonesia (Persero) Tbk cabang Manado gambaran yang lebih jelas tentang masalah yang diteliti.

2. Observasi,yaitu mengadakan pengamatan langsung pada tempat penelitian untuk mendapatkan data-data yang diperlukan sehubungan dengan kepentingan penelitian.

3. Studi kepustakaan yaitu menggunakan buku-buku dari berbagai sumber untuk mendapatkan data yang bersifat teoritis.

4. Dokumentasi yaitu informasi yang berasal dari catatan penting baik dari lembaga atau organisasi maupun dari perorangan.

\subsection{Metode Analisis Data}

Metode analisis data yang digunakan adalah metode kualitatif dimana penelitian dilakukan dengan mengumpulkan data-data yang bersangkutan dengan restrukturisasi kredit bermasalah dan membandingkan kesesuaian pengakuan, pengukuran, dan pengungkapan dengan Pernyataan Standar Akuntansi Keuangan No. 55 dan No. 60, Peraturan Bank Indonesia (PBI) dan Peraturan Akuntansi Perbankan Indonesia (PAPI).

\section{HASIL PENELITIAN DAN PEMBAHASAN}

\subsection{Hasil Penelitian}

PT. Bank Rakyat Indonesia (Persero) Tbk Cabang Manado, secara garis besar menjelaskan materi restrukturisasi kredit bermasalah terhadap debitur telah dibuat dengan berpedoman pada Peraturan Bank Indonesia (PBI), Pernyataan Standar Akuntansi Keuangan (PSAK) dan pedoman serta kebijakan akuntansi restrukturisasi kredit berdasarkan Pedoman Akuntansi Perbankan Indonesia (PAPI).

\section{Pengakuan Perlakuan Akuntansi untuk Proses Restrukturisasi Kredit} Tabel 4.1 Kategori Golongan Berdasarkan Tunggakan Angsuran Bulanan Kredit

\begin{tabular}{|l|l|l|}
\hline Golongan & Lama Tunggakan Angsuran & Kategori \\
\hline Golongan I & 0 hari & Lancar \\
\hline Golongan II & 1-90 hari & Dalam Perhatian Khusus \\
\hline Golongan III & 91-180 hari & Kurang Lancar \\
\hline Golongan IV & 181-270 hari & Diragukan \\
\hline Golongan V & Lebih dari 270 hari & Macet \\
\hline
\end{tabular}

\section{Pengukuran Perlakuan Akuntansi untuk Proses Rekstrukturisasi Kredit}

Sejak 1 Januari 2017, kredit bermasalah PT. Bank Rakyat Indonesia (Persero) Tbk cabang Manado diukur dengan metode penurunan nilai yaitu suatu kondisi dimana terdapat bukti objektif terjadinya peristiwa yang merugikan akibat satu atau lebih peristiwa yang terjadi setelah pengukuran awal aset tersebut dan peristiwa merugikan yang berdampak pada estimasi arus kas masa datang aset keuangan yang dapat diestimasi secara handal. 


\section{Pengungkapan dan Pencatatan untuk Proses Restrukturisasi Kredit}

Pengukuran tentang kredit bermasalah, beserta metode dan kebijakan akuntansi yang digunakan oleh PT. Bank Rakyat Indonesia (Persero) Tbk cabang Manado. diungkapkan dalam catatan atas laporan keuangan. PT. Bank Rakyat Indonesia (Persero) Tbk cabang Manado telah menggunakan sistem pencatatan menggunakan komputer yang mempermudah pencatatan dan pelaporan keuangan pada akhir periode.

\subsection{Pembahasan}

\subsubsection{Analisis Penerapan Peraturan Bank Indonesia (PBI) tentang Restrukturisasi Kredit}

Tabel 4.2 Perbandingan antara PBI dengan Perlakuan di PT. Bank Rakyat Indonesia (Persero) Tbk cabang Manado tentang Perlakuan Akuntansi Restrukturisasi

\begin{tabular}{|c|c|c|c|}
\hline \multirow[b]{2}{*}{ Isi PBI } & \multirow{2}{*}{$\begin{array}{c}\text { Perlakuan di PT. Bank Rakyat } \\
\text { Indonesia (Persero) Tbk cabang } \\
\text { Manado }\end{array}$} & \multicolumn{2}{|c|}{ Keterangan } \\
\hline & & Sesuai & $\begin{array}{l}\text { Belum } \\
\text { Sesuai }\end{array}$ \\
\hline $\begin{array}{l}\text { Tentang Perlakuan } \\
\text { Restrukturisasi Kredit berbunyi Bank } \\
\text { wajib menerapkan perlakuan akuntansi } \\
\text { restrukturisasi kredit sesuai dengan } \\
\text { standar akuntansi keuangan yang } \\
\text { berlaku. Perlakuan akuntansi untuk } \\
\text { restrukturisasi kredit antara lain } \\
\text { diterapkan untuk: } \\
\text { a. pengakuan kerugian } \\
\text { b. pengakuan pendapatan } \\
\text { bunga dan penerimaan lain }\end{array}$ & 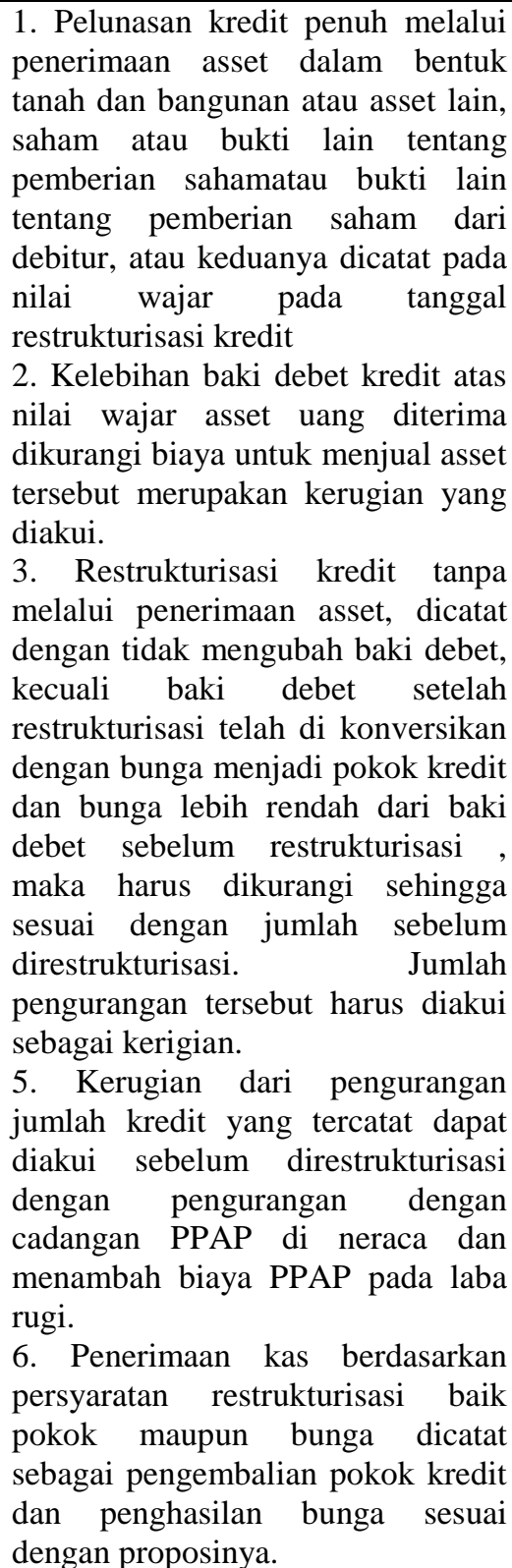 & $\checkmark$ & \\
\hline
\end{tabular}

(Sumber: Olahan 2017) 


\subsubsection{Perbandingan Pengakuan Restrukturisasi Kredit Bermasalah dalam Kerugian Penurunan Nilai Berdasarkan PSAK No. 55 (Revisi 2011) dengan PT. Bank Rakyat Indonesia (Persero) Tbk cabang Manado \\ Di bawah ini merupakan perlakuan akuntansi menyangkut restrukturisasi kredit} berdasarkan PSAK No. 55 (revisi 2011).

1. Seluruh kewajiban keuangan diukur berdasarkan biaya perolehan di amortisasi dengan menggunakan suku bunga efektif telah sesuai dengan PT. Bank Rakyat Indonesia (Persero) Tbk cabang Manado yaitu biaya perolehan di amortisasi dan diakui menggunakan suku bunga efektif.

2. Pengakuan perhitungan nilai kini berdasarkan estimasi arus kas masa depan atas aset keuangan piutang yang dapat di hasilkan dari pengambil alihan agunan di kurangi biaya-biaya untuk memperoleh atau menjual agunan telah sesuai dengan PT. Bank Rakyat Indonesia (Persero) Tbk cabang Manado yaitu arus kas masa depan atas aset keuangan diakui berdasarkan pengambil alihan agunan di kurangi biaya-biaya untuk memperoleh dan menjual agunan.

3. Laporan posisi keuangan diakui jika aset yang dijaminkan oleh pihak penerima memiliki hak untuk menjual atau mentansfer kembali telah sesuai dengan PT. Bank Rakyat Indonesia (Persero) Tbk cabang Manado yaitu jaminan atau agunan dalam posisi keuangan konsolidasi diakui, bila pihak penerima memiliki hak untuk menjual atau mentransfer kembali.

4. Pada setiap tanggal neraca entitas mengevaluasi apakah terdapat bukti yang objektif bahwa aset keuangan mengalami penurunan nilai telah sesuai dengan PT. Bank Rakyat Indonesia (Persero) Tbk cabang Manado yaitu evaluasi piutang di cek satu per satu pada setiap tanggal neraca bila terdapat bukti objektif penurunan nilai.

\subsubsection{Perbandingan Pengukuran Restrukturisasi Kredit Bermasalah dalam Kerugian Penurunan Nilai Berdasarkan PSAK No. 55 (Revisi 2011) dengan PT. Bank Rakyat Indonesia (Persero) Tbk cabang Manado}

1. Estimasi arus kas masa depan dikaji ulang secara berkala untuk mengurangi perbedaan jumlah estimasi kerugiannya telah sesuai dengan PT. Bank Rakyat Indonesia (Persero) Tbk cabang Manado yaitu estiamsi kerugian atas aset di masa yang akan datang di kaji secara berkala, demi mengurangi jumlah kerugian.

2. Arus kas masa depan dari kelompok aset keungan yang penurunan nilainya dievaluasi secara kolektif, di estimasi berdasarkan kerugian historis yang pernah di alami beberapa tahun sebelumnya telah sesuai dengan PT. Bank Rakyat Indonesia (Persero) Tbk cabang Manado yaitu tingkat penurunan nilai yang telah dikelompokkan atau dieavaluasi secara kolektif untuk aset keuangan diukur berdasarkan kerugian historis.

3. Penghentian pengakuan terjadi ketika kontrak terkait pinjaman terakhir dan telah dipenuhi telah sesuai dengan PT. Bank Rakyat Indonesia (Persero) Tbk cabang Manado yaitu piutang atau pinjaman, penghentian pengakuan baik seluruhnya atau sebagian, erjadi pada saat piutang dilunasi semuanya.

4. Metode yang dipakai untuk pengukuran pencatatan penurunan nilai adalah metode penghapusan dan metode pencadangan telah sesuai dengan PT. Bank Rakyat Indonesia (Persero) Tbk cabang Manado yaitu metode pengukuran pencatatan penurunan nilai menggunakan metode pencadangan penghapusan piutang tak tertagih dengan mendebit cadangan kerugian penurunan nilai dan mengkredit piutang. 


\subsubsection{Perbandingan Pengungkapan Pengakuan Aset Keuangan berdasarkan PSAK 60 dengan PT. Bank Rakyat Indonesia (Persero) Tbk cabang Manado}

Laporan posisi keuangan:

1. Kategori aset keungan dan liabilitas keuangan telah sesuai dengan PT. Bank Rakyat Indonesia (Persero) Tbk cabang Manado yaitu bank membagi kategori aset keuangan dan liabilitas keuangan, dan nilai yang tercatat diungkapkan dalam laporan posisi keuangan.

2. Aset keuangan atau liabilitas keuangan yang diukur pada nilai wajar melalui laba rugi telah sesuai dengan PT. Bank Rakyat Indonesia (Persero) Tbk cabang Manado. Dalam PT. Bank Rakyat Indonesia (Persero) Tbk cabang Manado kelompok aset dan liabilitas diukur pada nilai wajar melalui laporan laba rugi adalah aset dan liabilitas keuangan dimiliki untuk diperdagangkan yang diperoleh atau dimiliki PT. Bank Rakyat Indonesia (Persero) Tbk cabang Manado terutama untuk tujuan dijual atau dibeli kembali dalam waktu dekat, atau dimiliki sebagai bagian dari portofolio instrument keuangan tertentu yang dikelola bersama untuk memperoleh laba jangkapendek atau position taking.

3. Saling hapus asset keuangan dan liablitas keuangan telah sesuai dengan PT. Bank Rakyat Indonesia (Persero) Tbk cabang Manado yaitu mengungkapkan saling hapus aset keuangan dan liabilitas keuangan jika hanya bank memiliki hak yang berkekuatan hukum

4. Agunan telah sesuai dengan PT. Bank Rakyat Indonesia (Persero) Tbk cabang Manado yaitu bank mengungkapkan agunan

5. Penyisihan kerugian kredit telah sesuai dengan PT. Bank Rakyat Indonesia (Persero) Tbk cabang Manado yaitu bank mengungkapkan akun penyisihan kerugian kredit dengan jelas

6. Instrumen keuangan majemuk dengan beberapa derivative melekat telah sesuai dengan PT. Bank Rakyat Indonesia (Persero) Tbk cabang Mando yaitu instrumen keuangan derivatif dinilai dan diakui dilaporan posisi keuangan konsolidasian pada nilai wajar dikurangi cadangan kerugian penurunan nilai.

\section{Tabel 4.7 Perbandingan Perlakuan Akuntansi Restrukturisasi Kredit dengan Cara Modifikasi Persyaratan Kredit 1}

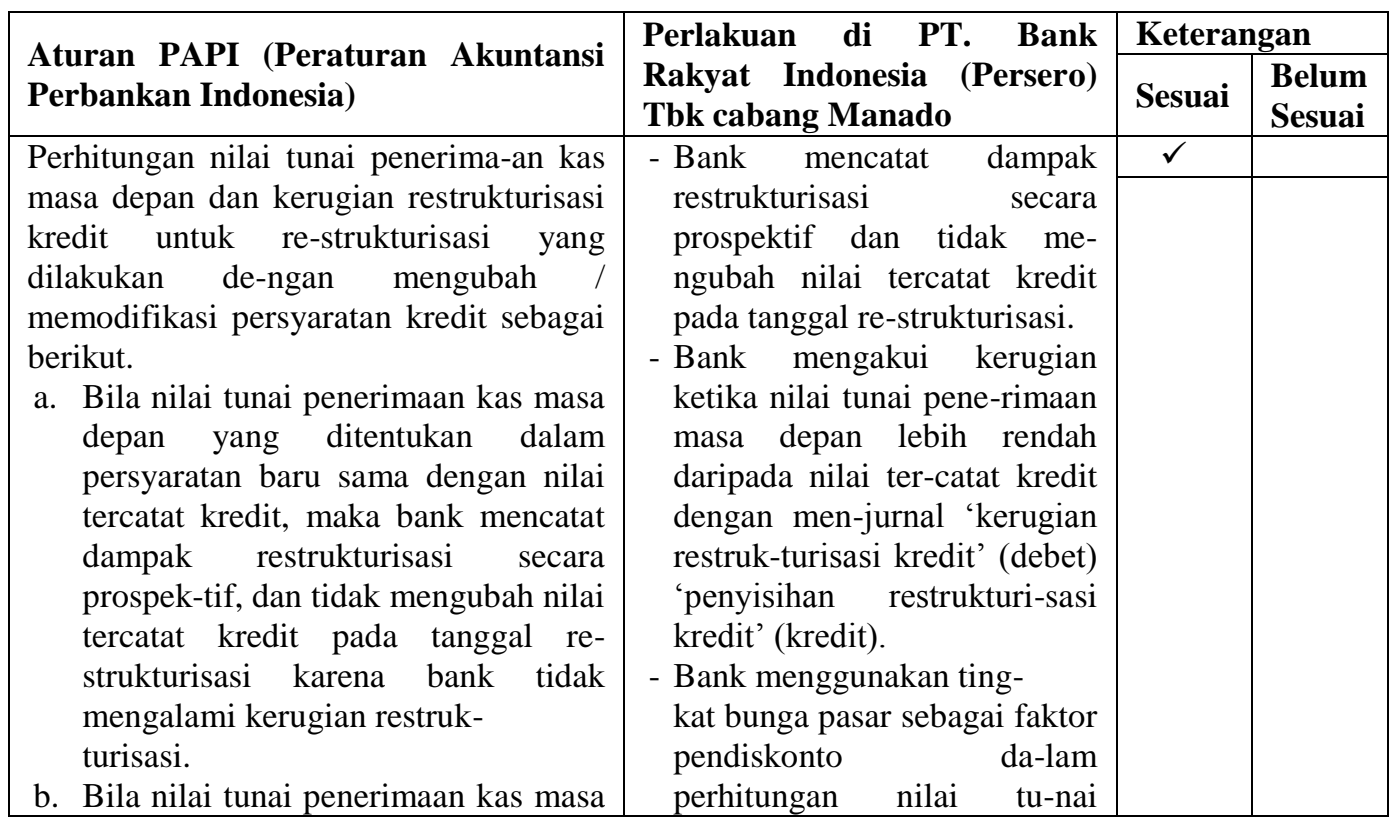




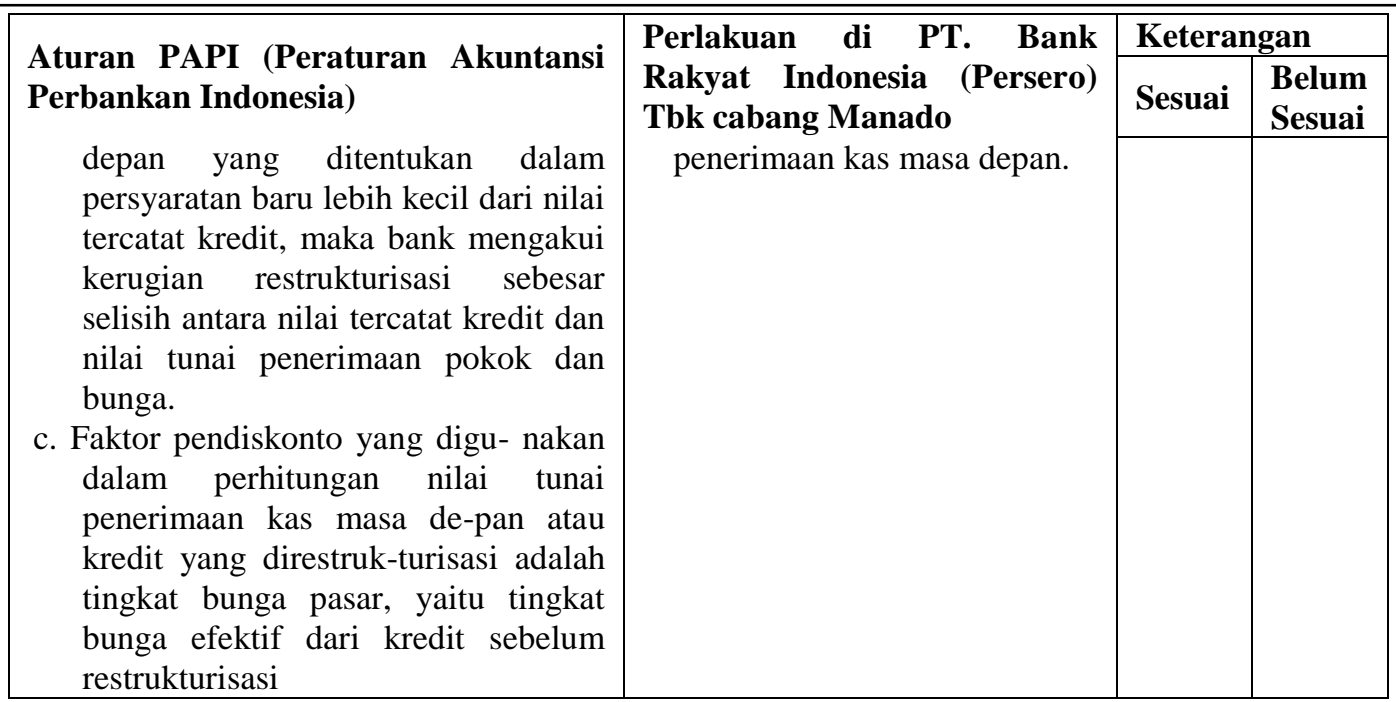

(Sumber: Olahan, 2017)

Restrukturisasi kredit dengan pengurangan pokok dan bunga, maka selain penghitungan nilai tunai penerimaan kas masa depan dan kerugian restrukturisasi kredit, maka perlu juga diperhatikan hal-hal sebagai berikut.

\section{Tabel 4.8 Perbandingan Perlakuan Akuntansi Restrukturisasi Kredit dengan Cara Modifikasi Persyaratan Kredit 2}

\begin{tabular}{|c|c|c|c|}
\hline \multirow[b]{2}{*}{$\begin{array}{l}\text { Aturan PAPI (Peraturan Akuntansi } \\
\text { Perbankan Indonesia) }\end{array}$} & \multirow{2}{*}{$\begin{array}{l}\text { Perlakuan di PT Bank Rakyat } \\
\text { Indonesia (Persero) Tbk } \\
\text { cabang Manado }\end{array}$} & \multicolumn{2}{|c|}{ Keterangan } \\
\hline & & Sesuai & $\begin{array}{l}\text { Belum } \\
\text { Sesuai }\end{array}$ \\
\hline $\begin{array}{l}\text { a. Pengurangan pokok dan/atau bunga } \\
\text { secara absolut, maka pe-ngurangan } \\
\text { pokok kredit dibe-bankan ke } \\
\text { penyisihan kerugian kredit. } \\
\text { Pengurangan bunga di-lakukan } \\
\text { dengan melakukan jurnal balik atas } \\
\text { tagihan kon- } \\
\text { tingensi dan tidak mengakui } \\
\text { kerugian. } \\
\text { b. Pengurangan pokok dan/atau bunga } \\
\text { secara kontigen / ber-syarat, } \\
\text { pengurangan pokok kredit } \\
\text { dibebankan ke penyi-sihan kerugian } \\
\text { kredit dan bank mengakui tagihan } \\
\text { kontingensi pokok. }\end{array}$ & $\begin{array}{l}\text { Bank membebankan pe- } \\
\text { ngurangan kerugian kredit ke } \\
\text { penyisihan kerugian kredit. } \\
\text { Pengurangan bunga dilakukan } \\
\text { dengan memba-lik jurnal atas } \\
\text { tagihan kon-tigensi dan tidak } \\
\text { menga- } \\
\text { kui kerugian. } \\
\text { Bank membebankan pe- } \\
\text { ngurangan pokok dan atau } \\
\text { bunga secara kontijen dan bank } \\
\text { mengakui tagihan kontingensi } \\
\text { pokok. }\end{array}$ & $\checkmark$ & \\
\hline
\end{tabular}

(Sumber: Olahan, 2017)

\section{KESIMPULAN DAN SARAN}

\subsection{Kesimpulan}

Kesimpulan dalam penelitian ini adalah:

1. PT. Bank Rakyat Indonesia (Persero) Tbk cabang Manado terkait pengakuan dalam oroses restrukturisasi kredit bermasalah menentukan penyisihan cadangan kerugian penurunan nilai kredit. Jika persyaratan kredit yang diberikan karena debitur mengalami kesulitan keuangan, maka akan diberikan penurunan nilai yang diukur dengan suku bungan efektif yang digunakan sebelum persyaratan diubah. Pengakuan atas cadangan kerugian penurunan nilai pada PT. Bank Rakyat Indonesia (Persero) Tbk cabang Manado sudah sesuai dengan Penerapan PSAK 55 (Revisi 2011) dimana 
perhitungan penyisihan kerugian penurunan nilai berdasarkan nilai tercatat menggunakan biaya perolehan armotisasi dan untuk pendapatan bunga atas aset keuagan yang mengalami penurunan nilai, tetap diakui atas dasr suku bunga yang digunakan untuk mendiskonto arus kas masa datang dalam pengukuran kerugian penurunan nilai.

2. PT. Bank Rakyat Indonesia (Persero) Tbk cabang Manado terkait dengan pengukuran dalam proses restrukturisai kredit bermasalah, proses pengukuran evaluasi pengukuran nilai dilakukan secara individual dan kolektif. Arus kas masa depan dari kelompok aset yang penurunan nilainya dievaluasi secara kolektif, diestimasi berdasarkan kerugian historis yang pernah dialami. Perlakuan pengukuran atas cadangan kerugian penurunan nilai pada PT. Bank Rakyat Indonesia (Persero) Tbk cabang Manado sudah sesuai dengan PSAK No. 55 (revisi 2011).

3. PT. Bank Rakyat Indonesia (Persero) Tbk cabang Manado terkait dengan pengungkapan dalam proses restrukturisasi kredit bermasalah membahas aset keuagan dan liabilitas keuagan dan disajikan pada laporan posisi keuangan. Pengungkapan aset keuagan yang diterapkan di PT. Bank Rakyat Indonesia (Persero) Tbk cabang Manado sudah sesuai dengan PSAK No. 60 (revisi 2011).

\subsection{Saran}

Saran yang dapat diberikan dari penelitian ini, yaitu sebagai berikut:

1. PT. Bank Rakyat Indonesia (Persero) Tbk cabang Manado wajib mempertahankan system pencatatan dan perlakuan akuntansi yang benar terhadap restrukturisasi kredit bermasalah agar jumlah kredit yang bermasalah dapat berkurang.

2. Pelaksanaan penyelesaian kredit yang dilaksanakan PT. Bank Rakyat Indonesia (Persero) Tbk cabang Manado khususnya dalam pelaksanaan restrukturisasi belum benar-benar mengikuti seluruh ketentuan mengenai restrukturisasi, sehingga terjadi pengulangan restrukturisasi (restrukturisasi kedua) untuk satu hutang dari debitur yang sama.

3. PT. Bank Rakyat Indonesia (Persero) Tbk cabang Manado sebaiknya mencoba melakukan restrukturisasi kredit dengan cara konversi kredit. Konversi kredit dalam hal ini, konversi pinjaman debitur dalam bentuk penyertaan modal pada perusahaan debitur. Dengan dilakukannya konversi kredit, maka outstanding credit debitur yang telah dikonversi, dikurangkan dari akun kredit. Konversi kredit dilakukan dengan mendapat saham perusahaan debitur. Dalam hal saham diserahkan nilainya lebih rendah dibandingkan total kewajibannya, maka sisanya masih menjadi kredit debitur.

\section{DAFTAR PUSTAKA}

Apriyanto, Benny. 2015. Penyelesaian Kredit Bermasalah Pada Bank DKI Jakarta Cabang Solo Melalui Jalur Non Litigasi. Skripsi. Universitas Atma Jaya Yogyakarta.

Ermawati. 2013. Kredit Macet Pada Perbankan Syariah. Skripsi. Universitas Gunadarma.

Firmansyah. 2013. Kewenangan Otoritas Jasa Keuangan (OJK) Sebagai Lembaga Pengawasan Perbankan di Indonesia. Skripsi.Universitas Hasanudin. Makassar.

Govanda, Mayfella. 2015. Analisis Perlakuan Akuntansi Kredit Bermasalah (NonPerforming

Loan) Sebelum Dan Sesudah PSAK No. 31 Efektif Dicabut. Skripsi. Universitas Lampung

Harnanto. 2009. Akuntansi Keuangan Lnjutan. Penerbit bpfe. Yogyakarta.

Hery. 2012. Cara Mudah Memahami Akuntansi Inti Sari Konsep Dasar Akuntans, Penerbit

Prend. Jakarta. 
Hery. 2013. Akuntansi Dasar, Penerbit PT Gramedia Pustaka Utama. Jakarta

Ismail. 2012. Akuntansi Bank: Teori Dan Aplikasi dalam Rupiah. Penerbit Kencana. Jakarta.

Ivana, Melissa. 2013. Restrukturisasi Kredit Oleh PT. Bank Rakyat Indonesia (PERSERO)

Tbk Cabang Kawi Malang Terhadap Perusahaan Otobus Putra Mulia Berkedudukan

Di kabupaten Malang. Skripsi. Universitas Brawijaya.

Jayanti, Andi. 2012. Perlakuan Akuntansi Kredit Bermasalah (NonPerforming Loan) Kesesuaianya Sebelum Dan Sesudah Pernuataan Standar Akutansi Kuangan No. 31 Efektif Dicabut Pada PT. Bank Negara Indonesia (PERSERO) Tbk. Skripsi.Universitas Hasanuddin Makassar.

Kasmir. 2014. Bank dan Lembaga Keuangan Lainnya. Penerbit PT Rajagrafindo Persada, Jakarta.

Kieso dan Wetgandt. 1995. Akuntansi Intermediate. Binapura aksara. Jakarta.

Kuncoro. 2009. Metode Riset untuk Bisnis dan Ekonomi. Penerbit Erlangga. Jakarta.

Lumempouw, Gricy. 2015. Analisis Perlakuan Akuntansi Terhadap Restrukturisasi Kredit Bermasalah Pada PT. Bank Sulut. Skripsi. Universitas Sam Ratulangi Manado.

Lutfiani, Dwi. 2013. Perlakuan Akuntansi Kredit Bermasalah (NonPerforming Loan) Kesesuaiannya Pernyataan Standar Akuntansi Keuangan No. 31 Efektif Dicabut Pada PT. BPR Wilis Putra Utama Cabang Banyuwangi. Skripsi. Universitas Muhammadiyah Jember.

Pamungkas, 2015. Perlakuan Akuntansi Kredit Bermasalah (Nonperforming Loan) Sebelum dan Sesudah Pernyataan Standar Akuntansi Keuangan No. 31 Efektif Dicabut Pada PT. Bank Negara Indonesia (Persero) Tbk. Skripsi.Universitas Negeri Yogyakarta.

Pontoh, Winston. 2013. Akuntansi Konsep dan Aplikasi, Penerbit Halaman Moeka Publishing. Jakarta Barat.

Rafsanjani, Rizqi. 2013. Perlakuan Akuntansi Kredit Bermasalah Setelah PSAK No.31 Efektif Dicabut Pada PT. Bank Tabunngan Negara. Skrispi. Universitas Negeri Yogyakarta.

Rivai, Veithzal Dkk., 2013. Commercial Bank ManageMent: Manajemen Perbankan Dari Teori Ke Praktik. Edisi 1. Cetakan 1. Jakarta: Rajawali Pers.

Sugiyono. 2012. Metode Penelitian Pendidikan Pendekatan Kuantitatif, Kualitatif, dan R\&D. Penerbit Alfabeta, Bandung.

Sujarweni. 2015. Akuntansi Sektor Publik. Penerbit Pustaka Baru Press. Yogyakarta.

Sunyonto D. 2013. Metodologi Penelitian Akuntansi. Cetakan Satu. Bandung: Refika Aditama.

Suwardjono. 1992. Gagasan Pengembangan Profesi dan Pendidikan AKkuntansi di Indonesia. Yogyakarta.

Warren, Carl S, Reeve, James M, dan Duchac Jonathan E. 2014. Pengantar AkuntansiAdaptasi Indonesia. Edisi 25. Salemba Empat. Jakarta 